\title{
オーロラの光と人の感性について*
}

稲垣照美*1, 宮内一美*2, 木 村尚 美*2

\section{Kansei Estimation on Luminescence of Aurora}

\author{
Terumi INAGAKI*3, Kazumi MIYAUCHI and Naomi KIMURA \\ ${ }^{* 3}$ Department of Mechanical Engineering, Ibaraki University, \\ 4-12-1 Nakanarusawa, Hitachi-shi, Ibaraki, 316-8511 Japan
}

\begin{abstract}
The beautiful and magnificent light of aurora is one of the most wonderful phenomena among natural resources that we can observe. In this study, from the viewpoints of Kansei engieering, we focused on the hue of light of aurora, and we examined whether it causes the human spirit any effects or not by using various statistical analysis and Kansei analysis. It was revealed that there is a high possibility that the sufficient cure effect exists in the light of aurora. This research is the first basic trial turned to the creation of cure spaces for hospice and welfare facility. We also aim at developing a cure equipment by applying the light of aurora to hospice and medical facilities in future.
\end{abstract}

Key Words: Hue, Luminescence, Welfare, Kansei, Aurora

\section{1. 粕 論}

近年, 多くのマスメディアでは, ストレスや情緒 不安定に起因寸る中高年の自殺や青少年が引き起こす 事件・事故を取り上げている. また老人施設やホスピ 不医療の現場では，精神的な緩和ケアの重要性が希求 されている.こうした現状を踏まえると，現代人は常 に何らかの形で癒しを求めているのではないか，一方， 自然環境には，そよ風や川のせせらぎなど人に快啇感 をもたらすと言われている $1 /$ f ゆらぎを有する現象が 存在することが知られている ${ }^{(1) （ 2) . ~(2) ~}$ 物質的な豊かさは, 高度消費社会を生み, 開発に伴う 森林伐採・自動車の排気ガスによる大気污染・生活廃 水による河川の污染などの自然環境破壊を引き起こし， 元来自然が有する瘷し効果の恩恵を受けづらくしてい る. 著者らは, これまでホタルの光と人の感性につい て研究を行い, 発光パターンやその色相変動には 1 / f ゆらぎ現象が存在し，それが人の感性に影響を与える ことを明らかたした ${ }^{(3)} \sim(6)$.

本研究では, 極北の地の夜空を壮大に彩り, 地上 で見られる自然現象のうちで最も素晴しいものの一つ であるオーロラの光を取り上げ，それが人々の精神に 及ぼす癒しの効果を考察し, 検証した. すなわち, 才 一ロラが有する光のゆらぎ, 色相心理と感性情報計測

\footnotetext{
* 原稿受付 2005 年 12 月 14 日.

*1 正員, 茨城大学工学部(要316-8511 日立市中成沢町 4-121).

$* 2$ 茨城大学大学院理工学研究科.

E-mail : hotaru@mx.ibaraki.ac.jp
}

などの面からオーロラの光と人の感性について考察し た. さらに，オーロラの光や色相変動が人の精神にど のような心理的効果をもたらすのかについても併せて 検討した. 今後は, オーロラの光を応用した瘉し機器 をホスピスや医療施設一導入することを目指す.

\section{2. 計測およひ解析方法}

\section{2 - 1 光の㖕測}

オーロラとは, 宇宙から降り注ぐ高速の電子や陽 子が，地球の上層大気，主に酸素や窒素と衝突した時 に発光する現象である. ほとんどのオーロラは, 酸素 原子と窒素原子によって生み出されていると言っても 過言ではない. したがって, オーロラの色は, 酸素と 窒素が持つそれぞれの性質によって決まる. ある瞬間 に現れたオーロラの全体像をオーロラ・オーバルと言 うが, オーロラ・オーバルは南北両半球に同時に出現 し，それぞれ極地方を囲むようにリング状に広がるが， 地上からは地平線に邪魔をされてオーバルの一部しか 見ることはできない，また，地上から観察する場合， 緯度によってもオーロラの色相が異なることが知られ ている. オーロラには, 様々な形態があり, 代表的な ものとしてカーテン状のものや，コロナ状のものなど が挙げられる.

本研究では, オーロラの光のゆらぎ特性に着目した ほか, その光がどのような波長带に分布し, 人がその 色相に対してどのような感性を抱いているのかについ ても着目した. 図 1は，オーロラ計測システムの概略 


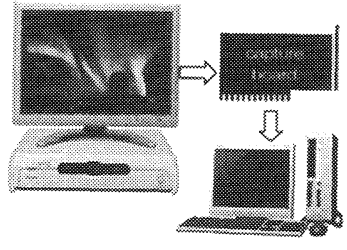

Fig. 1 Schematic Diagram of Measuring Luminance Information of Aurora

を示したものである. オーロラの光に対する画像処理 法は，前報（6）と基本的に同様である. まず，才一 ロラの動画像は, 画像入カソフトウェア ( (株) ライ ブラリ一製 Cosmos Capture）を用いてコンピュータ に取り込んだ. その際，ビデオ映像の時間分解能が 30 [frame / sec] であることからサンプリングレートを 30 [Hz] とし, 総数 1024 [frame], 時間にして $34.1[\mathrm{sec}]$ の動画像をパソコンに取り込んだ. なお, オーロラの 映像は，極地方において撮影されたメディア（付録参 照）を活用した. この際, 測定点は, オーロラのパ ソコン画面上における移動範用内において考察するた め, 図 2 に示すように，オーロラの大きさ・動きに合 わせ, 10 [pixell おきに垂直方向に 50 点, 水平方向に 65 点とした. 次に, オーロラの輝度 - 色相情報に関 する動画像は，画像濃度変位量解析ソフト（（株） ライブラリー製 Gray－Val32）を用いて，モノクロお よびR, G, B 成分に変換し, 時系列データとして 構筑した. さらに， R， G， B 成分それぞれの輝度 変動を色度座標に変換し, XYZ 表色系あるいは $\mathrm{X}_{10} \mathrm{Y}_{10} \mathrm{Z}_{10}$ 表色系に当てはめることによってオーロラの 光の主波長を算出した. なお，オーロラのビデオ映像 は，すべてフルカラーである.

また, 本研究では, 動的なオ一ロラの光を追跡し た際の輝度変動，および座標変動 (輝度の空間変動) についても測定を行った. すなわち, 測定は, オーロ ラの動きに合わせて任意に設定した矩形内における濃 度 (輝度) の重心を追跡し, 計測領域を移動させなが ら重心の輝度と座標を計測した。計測領域のサイズは, パソコン内の画像上にして面積 $10 \times 10$ [pixel から 70 $\times 70$ [pixel]まで任意に変化させ，測定を行った。 なお， 測定領域の位置は，オーロラの光に合わせて任意の位 置に設定した.

本研究では, 計測対象となるオーロラの元映像に, 付録に列記した映像メディアを利用したため，撮影機 材や条件によっては撮影された色相情報が異なる可能 性があった. そこで, 一連の研究 (6) で採用した手法

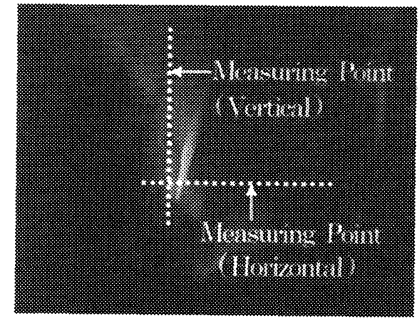

Fig. 2 Schematic Diagram of Measuring Points of Aurora

が普遍的な色相情報を取得する上で有効であることを 示すため, 4 種類の撮影機材 (京セラ製DV-L200, シ ヤーブ製 VLPP7，パナソニック製.Lumix FX-8，リコ 一製 Caplio R2S) でJS 標準色票を撮影し，同様な色 相解析を行った.

\section{2・2 イメーシ調查，官能評価およひ因子分析}

本研究では，オーロラの光といえばどのような言 葉が連想されるかについてアンケートを実施し, 回 収・分析した．その際，意見サンプルをいくつかの代 表的なキーワードに集約して整理し，人がオーロラの 光にどのような感性イメージを抱いているのかについ て考察を進めた. 意見サンプル総数は, 様々な年齢階 層の男女約 230 人である.さらに, SD（Semantic Differentials）法に準拠した官能評価を行った. SD 法 とは，相反する意味をもつ形容詞対を複数種類用意し， 被験者が評価対象に対して感じた程度を定量的に表す 方法で, 対象に対する心理評価を行う際に用いる手法 である. サンプル総数は，老若男女問わず 54 人であ った. 後述する表 3 に, 質問項目を示す. なお, 尺度 は7段階であり，得られた結果に基ついて因子分析を 行った. 因子の抽出法には主因子法を用い，共通性の 初期值を SMC ( Squared multiple correlation coefficient）法により推定し，斜交回転により最終的な 因子を決定した. SMC 法とは, 重決定係数を初期推 定值として用いて，他のすべての測定変数から因子を 重回州予測して求める方法である.

\section{3. 結果および考察 $3 \cdot 1$ 色相解析法の妥当性}

図 3 は, 前述した 4 種の撮影機材を用いて, JS標 準色票における代表的な赫について撮影し, 計測した 主波長を波長帯毎のヒストグラムで表したものである. 主波長の平均值及び標準偏差は，それぞれ 626.12 [nm], $8.40[\mathrm{~nm}]$ である. 図4は, JS標準色票におけ る代表的な緑について撮影し，主波長を波長帯毎の七 
ストグラムで表したものである. 主波長の平圴値は， 52024 [nm], 標準偏差は9.84 [nm]である. 図5は, JS 標準色票における代表的な青について撮影し，主 波長を波長帯毎のヒストグラムで表したものである. 平均值及び標準偏差は，それぞれ 475.76 [nm]，203 [nm]である.

ここで使用した JIS 色票は，主波長 $620.4[\mathrm{~nm}]$ 赤 (マンセル值 $5 \mathrm{R} 4 / 14$ ), 主波長 5262 [nm] の緑(マン セル值 5G4/10)，主波長 475.1 [nm]の青(マンセル值

Kyocera DV-L200

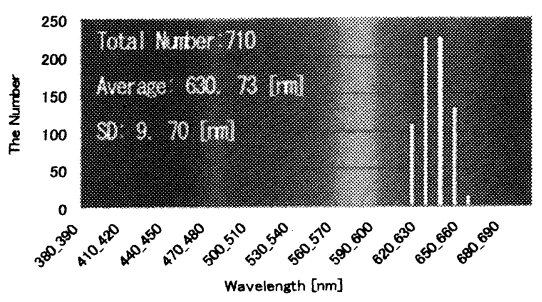

Panasonic Lumix FX-8

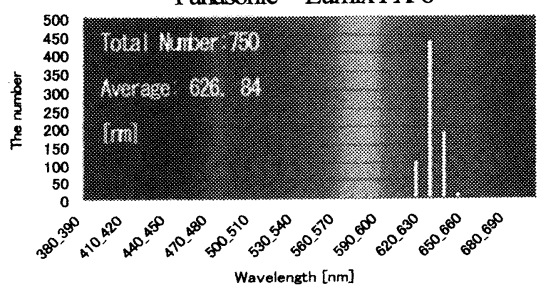

5B 4/8)である.これらの值と図 3〜 5に示した算出 した主波長の平均值とを比較すると，それぞれの撮影 機材での值は色表の值と誤差の範用内でほぼ一致して おり, 本研究で使用した色相解析法が妥当であると見 なした. すなわち, 撮影機材の異なる条件下において も，元映像の色相值とほぼ同等の色相值を再現できる ことがわかる.

\section{$3 \cdot 2$ 色相の解析}

図 6 およひ図 7 は，アラスカ地方における代表的

Fig. 3 Hue Distributions ( Red) Measured with Four Kinds of Cameras
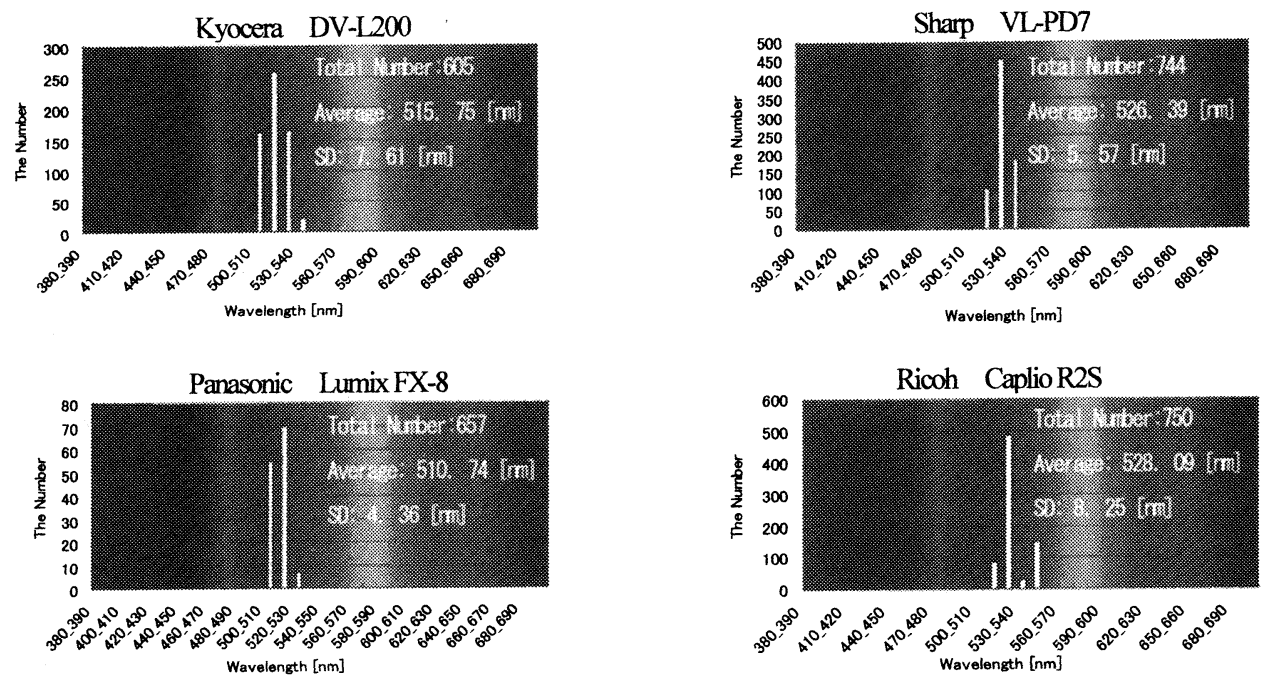

Fig. 4 Hue Distributions (Green) Measured with Four Kinds of Cameras 

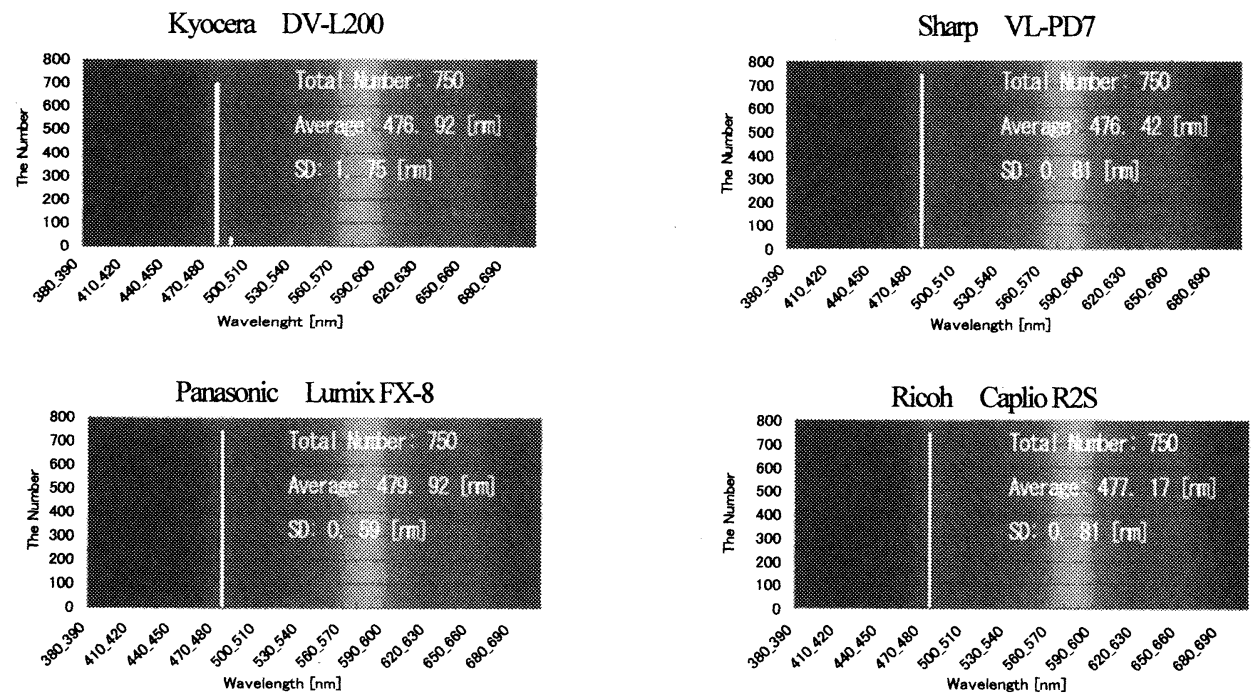

Fig. 5 Hue Distributions (Blue) Measured with Four Kinds of Cameras
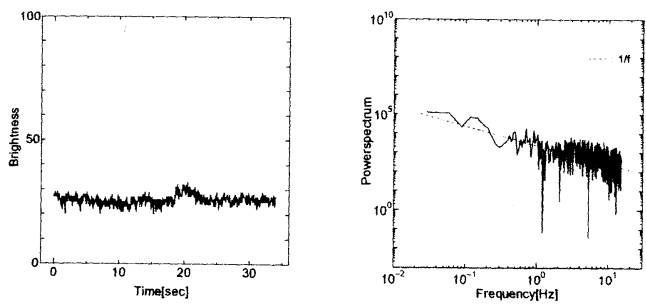

Fig. 6 Luminance Information of Original Data (left) and Power Spectrum (right). Dashed Line Means the Gradient of $1 /$ f.

な Purplish Blue のオーロラの光の, 任意の 1 点にお ける，代表的なモノクロと R, G, B 成分の輝度変動 およびそれらを FFT 解析したパワースペクトルを表 わしたものである. 図6およひ図7のパワースペクト ルから, 高周波数帯域を除いた約 $20 \sim 3.0[\mathrm{~Hz}]$ より低

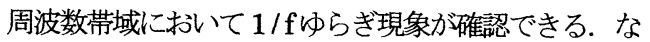
お，どのような任意の点を FFT 解析しても，そのス ペクトル性状は, 統計的な見地からも類似であった。

図 8 は，アラスカ地方における代表的なオ一ロラ の光の主波長を波長帯毎のヒストグラムで表した一例 である. これは, 主に Purplish Blue を中心とした色 相帯のオ一ロラを色相解析した結果であり, 主波長帯 は440 480 [nm], 平均值 467.1 [nm], 標隻偏差 9.094 [nm] である. 図 9 は, 主波長変動の時系列情報とそ のパワースペクトルを示した一例である. やはり約 20〜3.0 [Hz]より低周波数帯域において $1 /$ fゆらぎ現
象が確認できる. 図 10 は，縦方向 47 力所の測定点に ついて，それぞれの点におおけ色相の主波長変動を FFT 解析し，パワースペクトルで表した際のスペク トルの傾き（n 值）をヒストグラムで表したものであ る. なお，以降の計測（他の計測対象）では，測定点 をそれぞれのオーロラの動きに応じてその都度変更し てある. 図 10 のヒストグラムから，1.0 付近を中心に n 值が分布していることがわかる. すなわち，青味を 帯びたオ一ロラの色相の主波長変動においても, 高い 頻度で1/fゆらぎの変動をしていることが示された.

図 11 は，アラスカ地方で観測された，Reddish Orange を中心波長に持つオーロラの主波長を波長帯 毎のヒストグラムで表した一例である. 図 11 のオ一 ロラにおける波長帯は，590～620 [nm], 平均値 600.4 [nm], 標準偏差 $8.602 \mathrm{hml}$ である. 図 12 は, 主波長 変動の時系列情報とそのパワースペクトルを示した一 

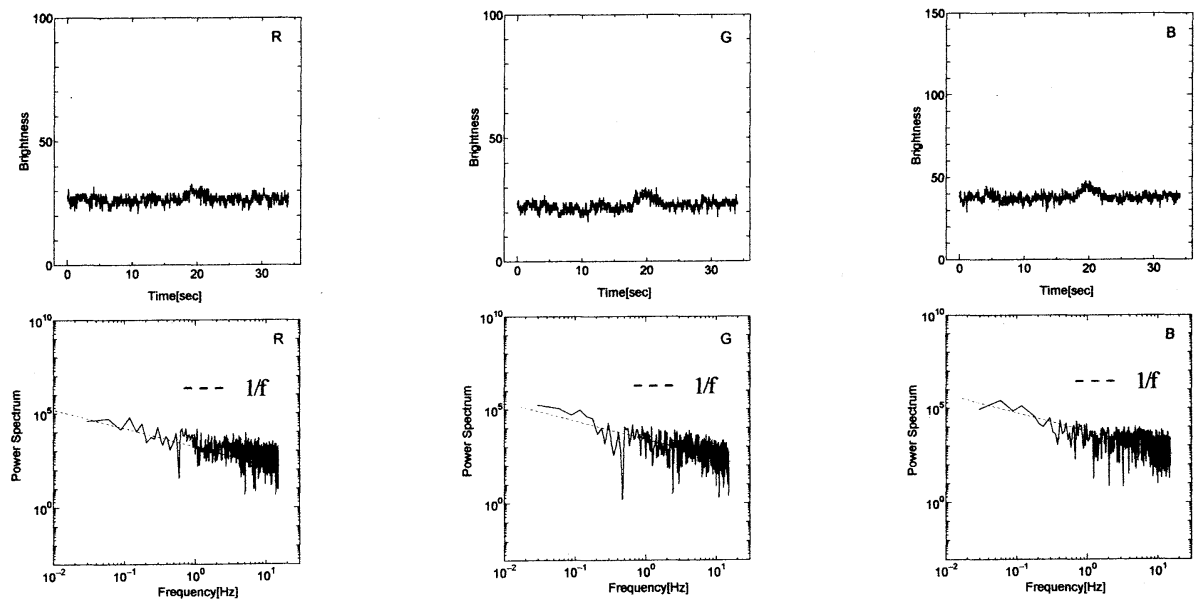

Fig. 7 Luminance Information of $R, G, B$ Components (upper) and Power Spectrum (lower)

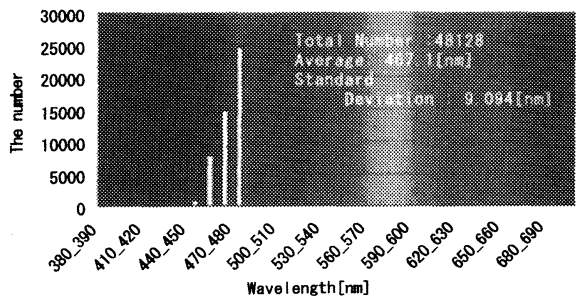

Fig. 8 Distribution of Hue in Wave Length (Purplish Blue)

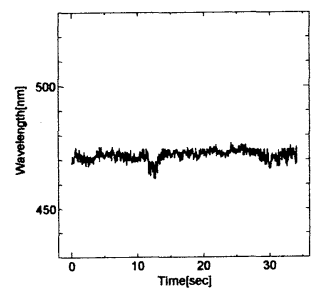

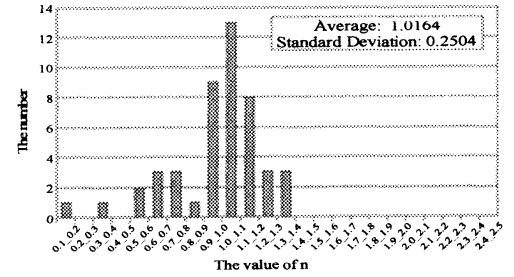

Fig. 10 Gradient of the Power Spectrum of the Hue (Purplish Blue)

Fig. 9 Temporal Changes of Hue (left) and Its Power Spectrum (right) (Purplish Blue). Dashed Line Means the Gradient of $1 / f$.

例である. 約 $20 \sim 3.0[\mathrm{~Hz}]$ より低周波数帯域において 1 / fゆらぎ現象が確認できる. 図 13 は, 縦方向 10 点, 横方向 10 点の測定点について; それぞれの点におけ る色相の主波長変動を FFT 解析し, パワースペクト ルで表した際のスペクトルの傾き（n 值）をヒストグ ラムで表したものである. 図 13 のヒストグラムから, 0.8 付近を中心に $\mathrm{n}$ 值が分布していることがわかる. すなわち, 赫を帯びたオ一ロラの色相の主波長変動

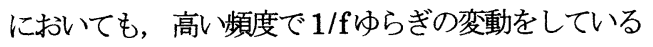
ことが示された.
図 14 は，極地方で観測された，Yellowish Groenを 中心波長に持つオ一ロラの主波長を波長帯毎のヒスト グラムで表した一例である. 波長帯は，540～570 [nm], 平均值 551.8 [nm], 標準偏差 2178 [nm] である. 図 15 は，主波長変動の時系列情報とそのパワースペ クトルを示したものである. 約 $20 \sim 3.0[\mathrm{~Hz}]$ より低周 波数帯域において 1 / f ゆらぎ現象が確認できる. 図 16 は，縦方向 34 点の測定点について，それぞれの点 における色相の主波長変動を FFT 解析し, パワース ペクトルで表した際のスペクトルの傾き（n 值）をヒ 


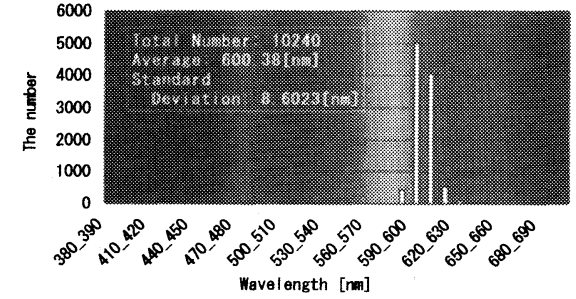

Fig. 11 Distribution of Hue in Wave length (Reddish Orange)

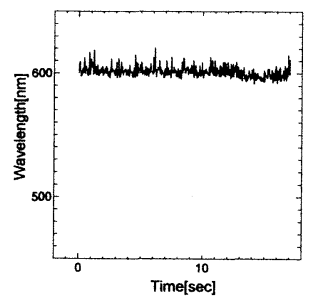

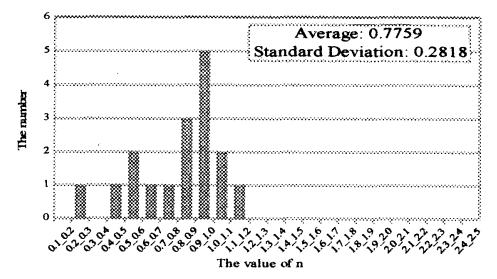

Fig. 13 Gradient of the Power Spectrum of the Hue (Reddish Orange)

Fig. 12 Temporal changes of Hue (left) and Its Power Spectrum (right) (Reddish Orange) Dashed Line Means the Gradient of 1/f.

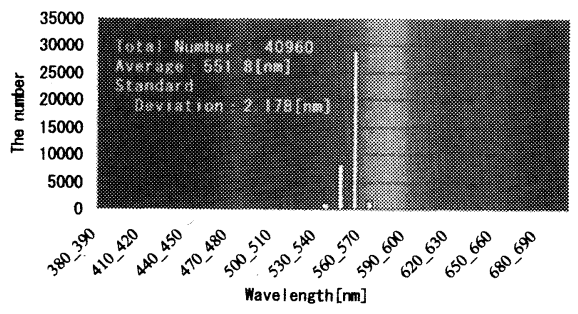

Fig. 14 Distribution of Hue in Wave length (Yellowish Green)

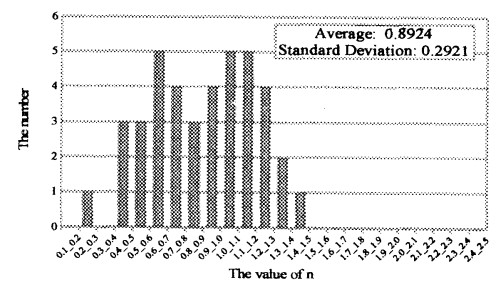

Fig. 16 Gradient of the Power Spectnum of the Hue (Yellowish Green)
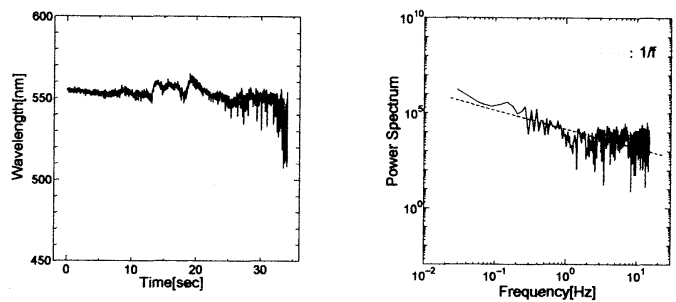

Fig. 15 Temporal Changes of Hue (left) and Its Power Spectrum (right) (Yellowish Green) Dashed Line Means the Gradient of 1/f.

ストグラムで表したものである. 図 16 のヒストグラ ムから，0.9 付近を中心に $\mathrm{n}$ 值が分布していることが わかる. すなわち， 緑味を帯びた色相の主波長変動 においても, 高い頻度で 1 / fゆらぎの変動をしている ことが示された.
以上の $1 / \mathrm{f}$ 変動現象について, 主波長変動が有す る $\mathrm{n}$ 值は, $0.8 〜 1.1$ を中に分布しているが, 誤差の 範囲内であり，いずれにも $1 / \mathrm{f}$ ゆらぎと同等な現象と 考えて良い. なお, 本研究では, 計測対象となる各ビ デオ映像の撮影条件がスペクトルに及ぼす影響を明ら 

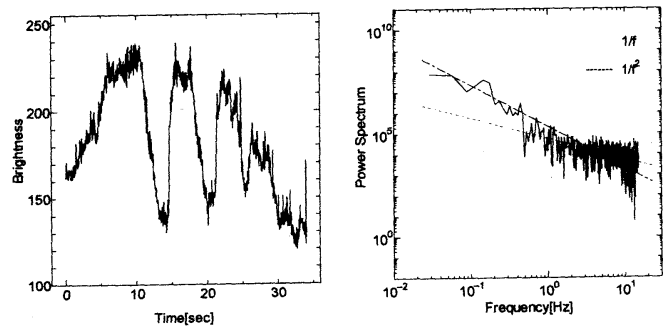

Fig. 17 Luminance Information of Transient

Spatial Fluctuation and Power Spectrum
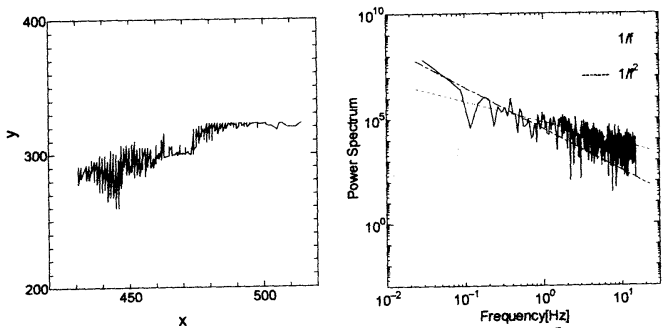

Fig. 18 Spatial Coordinates Fluctuation of

Brightness and Power Spectrum

かにするため, 測定されたオーロラの輝度・色相変動 の時系列情報を，それぞれの平均値で除した相対值を もって FFT 解析も行ってみた. その結果, スペクト ルのパワ一值が変化するものの, 統計的には同一のス ペクトル性状を示していた.一般に，スペクトル性状 のみを議論する場においては，絶対值でも相対值でも 変わらないといえる. なお, 一連のスペクトル性状は, 統計的な見地からも類似であった.

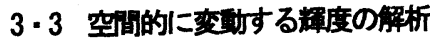

図 17 は，極地方における Yellowish Green を主波長 帯に持つオ一ロラの光について, 動的な光を追跡した 際の重心の輝度変動およびそれらを FFT 解析したパ ワースペクトルを表したものの一例である. 図 17 の パワースペクトルから, 約 $0.5[\mathrm{~Hz}]$ 以下の低周波数帯 域では $1 / \mathrm{f} 2$ ゆらぎ, 高周波数帯域では $1 / \mathrm{f}$ ゆらぎ現 象が確認できる.すなわち，人は 10 [s]から数十秒以 上に亘るオーロラのゆったりとした動きよりも， 0.1 [s] から数秒程度の比較的変化の早い小刻みな動きに 魅了されていることが示唆される.

図 18は，図 17 と同一の測定領域について，モノク ロの輝度の空間変動（座標変動）およびそれらを FFT 解析したパワースペクトルの一例を表したもの である. 図 18 のパワースペクトルから，ほぼ全域で 1/f ゆらぎ現象が確認できる. すなわち, 夜空を雄大 に彩るオ一ロラは，二次元的な空閒変動や広がりにも 人が興味を覚えるものと推察される.

\section{4 色相の心理的意味之官能評価}

本研究では，アラスカや極地方で見られるオーロ ラの色相解析を行い, 主に青紫, 黄赤, 黄緑の3色を 中心波長に持つオーロラの光について色相解析した. 表 1は，青紫，黄赤，黄緑それぞれの色相が有する心 理的意味合いを示している ${ }^{(7)}$. アラスカ地方で頻繁 に見られるオ一ロラは，特に青紫や黄緑を中心波長に 持つオ一ロラである.これらの色は，表に示すような 心理的意味合いを持ち，人を安らかな気分にさせる効 果があるとともに，神秘性も持ち併せていると考える

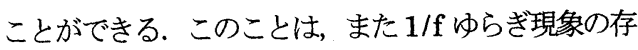
在と関連があるものと考えられる. 一方, 黄赤を中心 波長に持つオ一ロラは，色相そのものは人を元気にさ せる効果を持ち，人を癒す効果があるとされているが,

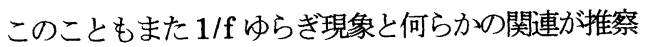
できそうである. しかしながら，図 10,13，16 から も明らかなように，青紫のオ一ロラが $1 / \mathrm{f}$ ゆらぎを出 現させる頻度が最も高いと言える. したがって, 人は, 青紫のオ一ロラに最も魅了され，幻想や神秘感を抱く とともに癒されているのではないであろうか。

また，本研究では，オーロラの光と言えばどのよ うな言葉が連想されるかについてアンケートを奉施し， 回収・分析した. 意見サンプル総数は，様々な年龄階 層の男女約 230 人である. 表 2 は，出てきた語句の中

Table 1. Psychological Meaning of Hue

\begin{tabular}{ll}
\hline Color & Psychological Meaningof Hue \\
Pupplish Bhe & Mystery, Sublimeness \\
Reddish Orange & Pleasure, Active \\
Yellowish Green & Peace, Calmness \\
\hline
\end{tabular}

Table 2. Totaling Results of the Questionnaire

\begin{tabular}{ll}
\hline Keywords & \multicolumn{1}{c}{ Answers } \\
Fantasy & Mysterious, Myth, Yearning, Dream \\
Fhuctuation & Curtain, Belt, Wavering, Robe of feathers \\
Grandeur & Largeness, Great, Space, Sky \\
Cald & Polarregions, NorthernEurope, Snow \\
Calor & Gradation, Spectrum, Iris, Vividness, Red, \\
& Blue, Green, Purple \\
\hline
\end{tabular}

Table 3. SDQuestionnaire

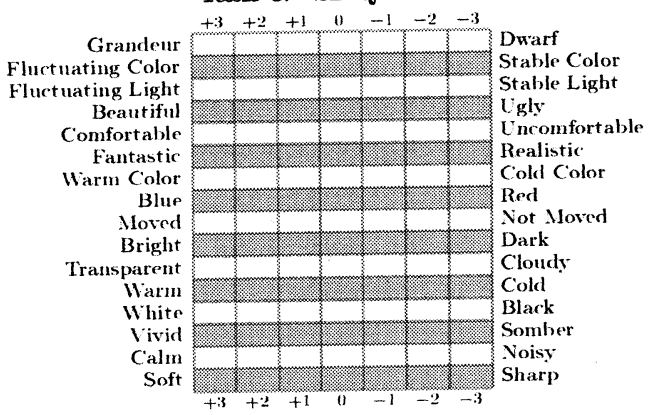




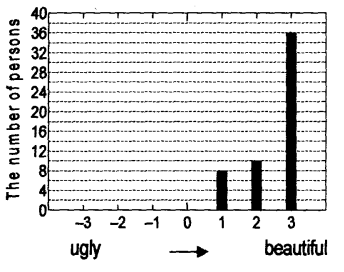

(a) Beautiful?

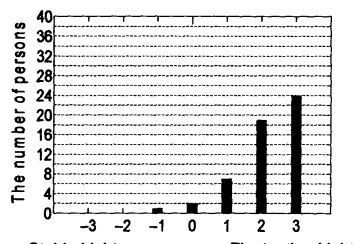

Stable Light

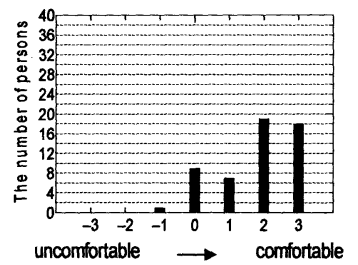

(b) Comfortable?

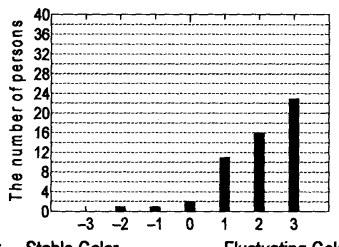

(†) Stable or Fluctuating Color

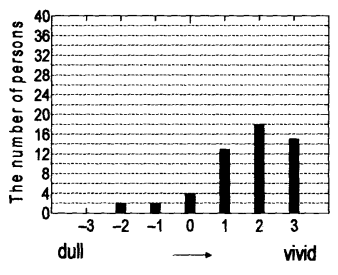

(c) Vivid or Dull

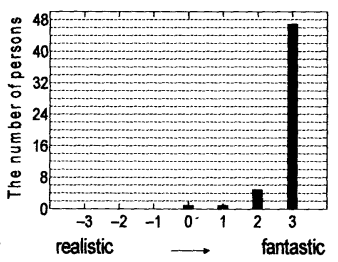

(g) Realistic or Fantastic

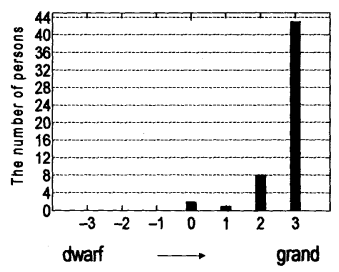

(d) Grandeur or Dwarf

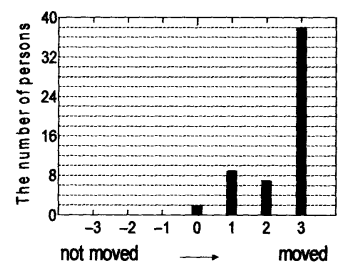

(h) Moved or Not Moved

Fig. 19Results ofSDMethod:From(a) to(h)Mean the Items of Questionnaire

から5つのキーワードを抽出し，それらのキーワード に関連する主な語句を挙げた結果を表にまとめたもの である. これらの因子にも，前述した色相心理のイ メージを連想させるものがあることがわかる．例えば, 青紫の「神秘的」などである. なお, 表 3 には, SD 法に準拠した官能評価の質問項目を示してある.

図 19 の（a）〜（h）は, 官能評価結果を表した ものである. これらの結果より, 大多数の人がオーロ ラの光や色を美しく幻想的にゆらいだものという認識 を持っており，オーロラに対して神秘的・感動的感情 や心地よさを抱いているといえる.

表 4 は, 斜交回転した後の因子負荷量を示したも のである. この結果を基に, 各観測変数を因子負荷量 の高いもので分類すると，第 1 因子への依存度が高い のは,“きれいだーきたない”，“心地よい一不快 だ”，“鮮やかだーくすんだ”，の3変数となった. また，第2因子に対しては，“ゆらいだ光だ一安定な 光だ”，“ゆらいだ色だ一安定な色だ”，の2変数, 第 3 因子に対しては，“壮大だ一矮小だ”，“幻想 的だ一現実的だ”，“感動的だ一無感動だ”の 3 変 数となった. これらの結果より，第 1 因子を「美」因 子と呼ぶことにした. また，第2因子を「ゆらぎ」因 子，第3因子を「神秘」因子と呼ぶことにした.すな わち, 従来からのオ一ロラに対する一般的な「神秘」

や，「美」などの印象に加え, 明度・彩度・色相のゆ らぎも，人に与える印象に大きく寄与しているとい える. したがって, イメージ調査, 官能評価およひ因
Table 4. Oblique Facto

\begin{tabular}{|c|c|c|c|}
\hline Questionmaire & Factor. 1 & Factor.2 & Factor. 3 \\
\hline Beautifiul-Dirty & 0.495 & 0217 & 0279 \\
\hline Comfortable-Unoomfortable & 0.757 & 0.006 & 0.042 \\
\hline Somber-Vivid & 0.968 & 0.01 & 0.386 \\
\hline Fluctuating & & & \\
\hline Luminescence & 0.066 & 0.907 & 0 \\
\hline FlucturatingColor-StableColor & 0.01 & 0.973 & 0.192 \\
\hline Grandeur-Dwarf & 0.057 & 0.07 & 0.671 \\
\hline Fantastic-Realistic & 0.315 & 0.016 & 0.895 \\
\hline Moved-NotMoved & 0.057 & 0.347 & 0.895 \\
\hline Contribution rate (\%) & 23316 & 24277 & 28972 \\
\hline Acoumulationocontribution rate (\%) & 23316 & 47.593 & 76565 \\
\hline
\end{tabular}

子分析の結果を光のスペクトル性状に照会すると，1/ f ゆらぎの存在は人がオーロラから受ける感性に癒し の影響を及ぼしているものと考えられる.

\section{4.おわりに}

本研究は, オーロラの光と人の感性について, オ 一ロラの発光パターンが有する色相のゆらぎを解析す るとともに，色相心理と感性情報計測の観点から実験 的な検討を加えたものである. その結果，以下のよう なことが明らかとなった.

- オーロラの輝度変動や色相変動には, $1 / \mathrm{f}$ ゆら ぎが存在し, 癒し効果の存在することが示された.

- 青紫や黄緑を中心波長帯に持つオーロラには, 色相心理学的意味合いからも癒し効果の存在すること が示された。

・ 人は, オーロラの光や色を美しく幻想的にゆ らいだものという認識を持っており, そうしたオーロ 
ラに対して神秘的・感動的感情や心地よさを抱いてい る人が多く見られた。

・ 従来からのオーロラに対する一般的な「神 秘」や美」などの印象に加え, 明度 - 彩度 ・色相 のゆらぎも人に与える印象に大きく寄与している.

\section{文献}

(1) T, Musya, The Approach of Fluctuation Approaching the Mystery of 1/f Fuctuation (in Japanese), (1998),p.60 - 64, p.108 - 150, NHKShuppan,

(2) T, Musya, The Science of Fluctuation (in Japanese), Vol. $1 \sim 9$, (1991 1999), Morikita Shuppan Co., Ltd.

(3) $\mathrm{T}$, Inagaki et al, $1 / \mathrm{f}^{\mathrm{n}}$ Fluctuating Phenomena in the Light Emission Pattern of Frefly and Its Healing Effect, Transactions of the Japan Society of Mechanical Engineers, Series C, Vol67, No.657 (2001-5) , pp.365 - 372

(4) N, Abe. et al, Kansei Estimation on Lumimescence of Frefly - The Fluctuating Characteristic of Light Emission Phenomena - , Journal of Japan Society of Kansei Engineering, Vol3, No.1, (2004) ,pp.35 - 44

(5) N, Abe. et al, Kansei Estimation on Luminescence of Firefly - Kansei Information Measurement and Welfare
Utilization, Journal of Japan Society of Kansei Engimeering, Vol3, No2 (2004) ,pp.41-50

(6) E, Hoshiba et al, $1 / \mathrm{f}^{\mathrm{n}}$ Fluctuating Phenomena in the Hue of Light Emission Pattern of Frefly and Its Healing Effect, Transactions of the Japan Society of Mechanical Engineers, Tobe Published

(7) T, Suenaga, Subject book Color Freedom Free (in Japanese), Syoubunsya, (1994),p.42 - 49

\section{付録}

- Daniel Osborne, The AURORA EXXLAINED, Geophysical Institute of the University of Alaska Faribanks

- Cinesell Japan,Inc, Aurora, Nippon Chown Co, Ltd

- TV Asahi Corporation, Aurora Fantasy, Polydor Co, Ltd

- MEXT / JAXA, The Birthplace of Aurora - The Science of Geomagnetosphere, Society for Promotion Space Science

- H, Kadowaki, AURORA Healing Lights, Synforest Inc

- Toshiba EMI, BGV Aurora Travel Finlandia II,Toshiba EMII 